partial as was possible to make them. Except for their brevity, and whatever errors may have been made in the official reports and returns from which they were compiled, they may be regarded as substantially correct; while the incidents I have here mentioned, and the names connected with them, will be found-by comparison-to accord with the records contained in the work to which I have referred.

\title{
A PLAINS ADVENTURE OF AN IOWA MAN.
}

\section{BY MARCELLUS PUGSLEY.}

In the fall of 1862, John Henry, with his family, moved from Albert Lea, Minn., to Harrison county, Iowa. He brought a herd of cows and young cattle and during the fall he eut on the surrounding prairies enough hay to winter his stock, two hundred tons or more. The following winter he occupied an abandoned house one and one-half miles from my father's home.

During the winter we became acquainted and attended several debates at the country schoolhouses, and as the war for the Union was in full swing, the questions were generally political. He and I being Republicans stood for the flag in every ease. Having a gift of strong language he did not spare the enemy.

About this time it became known that the great plains afforded almost unlimited pasturage both winter and summer. Mr. Henry decided to move to Colorado in the spring, and asked me to go with him at twenty dollars per month. I readily obtained the consent of my parents. I now know they were afraid I would go into the army as soon as I attained my majority, which would have been in a few months.

In April, Hotehkiss \& Wright, from Colorado, bought a herd of over one hundred cows and young cattle. It was agreed that we should go together. Our own herd consisted of one hundred and seventy, counting ealves. L. Crane and 


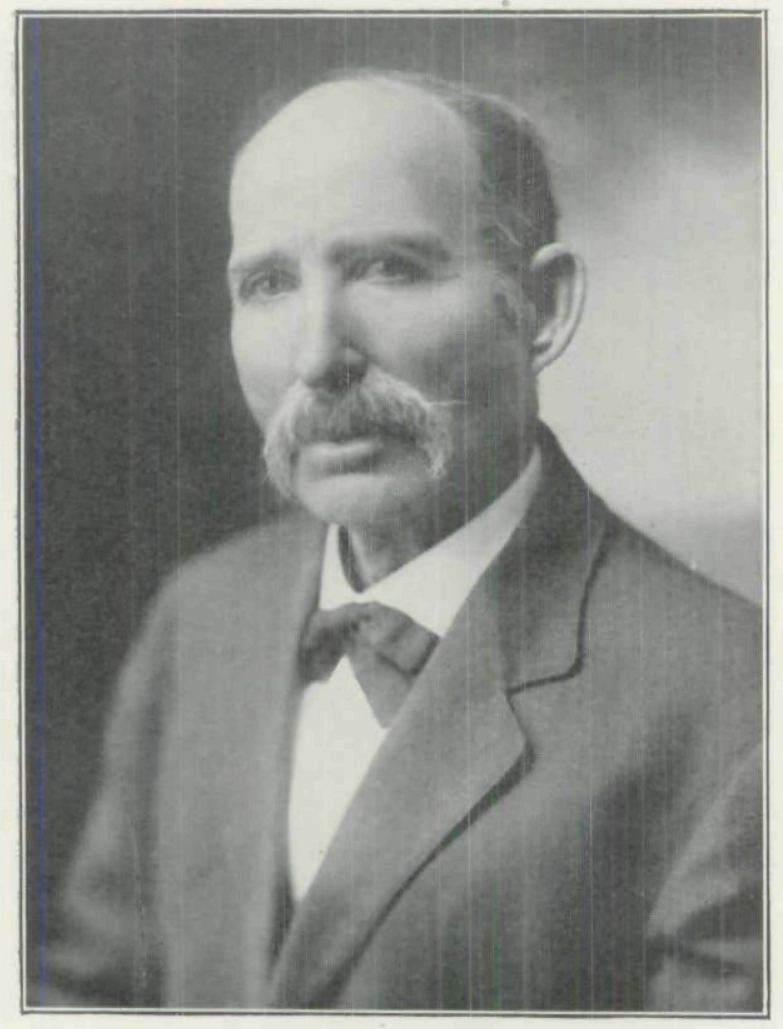

Marceleus Dugrey 
family and William Palmer, a single man, also joined us. They had some cattle, too, so that there were in the drove about three hundred and twenty-five head. We started on May 7th, 1863.

Mr. Henry's outfit consisted of two wagons, one drawn by mules and the other, of which I was driver, by oxen. On the way to Council Bluffs we were much annoyed by the eattle at large on the prairies running into our herd and insisting on going with us. We crossed the Missouri at Plattsmouth instead of Omaha. This saved crossing the Loup and fording the Platte at Fort Kearney. Also we had less travel, fewer farms to annoy us and pasturage was better. The ferry across the Missouri was propelled by oars, two on each side of the boat and two or more men to the oar. We had a time of it holding the eattle among the brush and timber on the east side, while the boat was taking them over at the rate of thirty or forty at a trip.

We had not gone more than twenty miles west of the Missouri when our four friends beeame dissatisfied with our slow progress, (Henry desiring to move slowly so as not to tire the cows and calves, some of which were very young), so they took their stock and went on. The family wagon was hitched behind my wagon and the mules were used to drive the cattle. When the stock was divided it was found that fifteen head were strays.

The Platte river from Kearney runs in a northeast eourse making an abrupt bend to the southeast at Fremont. The road divided, one branch following the river and the other going across through the hills, which were not at all high or steep. It was a most beautiful country, and we chose wisely in taking the cut-off road, which in places may have been twenty miles from the Platte. We joined the Platte route near the lower end of Grand Island where the road from Nebraska City came in.

It was here that I first saw a real freight train. Twenty wagons, the largest and strongest I had ever seen, were each loaded with three tons of corn and drawn by five yoke of oxen. When a train went into camp at night or for the noon rest, 
the wagons were drawn up in two semicireles, forming a corral with an opening at each end which could be closed by chains, to keep the eattle in while being yoked. This corral was large enough to hold the two hundred oxen required to haul the train. I saw many such trains on the way out, and they were all managed in about the same way.

The teamsters were called bull-whackers. Each man owned his own bed, which consisted of two or more blankets and did well enough when the weather was warm, but in the winter they "doubled up" and nearly froze. Each man took care of his share of the dishes which consisted of a tin plate and cup, a knife, fork and spoon. The cook, who drove the mess wagon, made the bread and coffee and fried the pork. They did not eall it pork; it was "sow-belly." When all was ready the men came with their dishes, received a couple of biseuits, a piece of meat, some molasses, a cup of eoffee with sugar to suit taste, all of which was keenly relished, as I know by experience. Each man washed his own dishes. The best way was to use a gunny-sack and ashes, with which things could be made to shine. Only a few were so nice, however, but then none had ever heard of ptomaine poison at that time. Really, bacteria and such things must have been very obliging not to take advantage of our ignorance in those days.

The country here was fine, slightly rolling, but supposed at that time to be a little too dry for safe farming. When we approached the Platte we descended quite a hill to gain the bottom lands. We camped by a small creek coming out of the hills and let the herd range off toward the Platte, which was studded with islands ranging in size from an acre or less to half a township. There was much timber on them, cottonwood and red cedar predominating. In some eases, especially farther up the river, the center of the island would be prairie. Still farther up-stream there was no timber.

The next morning we found that a fine ealf had died of blackleg. We made a drive of about ten miles and camped by a stream of clear, cold water that flowed from a large spring. There we missed a cow, so the next morning I was sent back to our former camp to look for her. I found her and a young 
calf as expected. I drove her up to the highway, where I stopped to feed my mule and eat lunch. A couple of Indians eame to me to inquire about the ealf that had died the night before. They wanted it, but were afraid that it had been poisoned for wolves. It took them a long time to make me understand, and in turn it took me a long time to assure them that it was all right. I did not then know the deadly character of anthrax.

When I resumed my journey the cow concluded that she did not want to go, so she whispered something into the calf's ear and it would not follow her. I don't know what she said to it but it was plain that there was an understanding between them. I roped the eow and the ealf laid down. Then I took the ealf upon the mule, supporting it with a large bell-strap that I had found, passing the strap over my right shoulder and under the ealf at my left side. Then I drove the cow, which hung back if I went ahead, and in that way I made camp about sundown.

When we arrived at Ft. Kearney we had plenty of company, for the roads from Atchison, Leavenworth and Omaha were all joined in one there. We had also a telegraph and stage line. The stage stations were twelve or fifteen miles apart. The horses were changed at each station and about every fourth or fifth station was a home station where the drivers changed for rest. The time required from Denver to the Missouri river was six days and the fare was one hundred dollars. From Kearney westward there was much travel and noise.

The ranches were at eonvenient places for hay and water, and were from six to twelve miles apart. Water could be had most anywhere on the Platte bottoms by digging wells from three to five whisky barrels deep. Water was drawn by a pole, rarely by an old fashioned sweep. It was good water, too.

The ranch buildings were of sod walls, with timbers, brush and hay for a cover, and on top of all, about a foot of earth. They were generally without a floor. The house was divided into a living room and a store room. The store sold a line of common groceries and always whisky. The other room where teamsters could cook and sleep was not much used in mild weather. There was also a stable large enough to aceom- 
modate about sixty span of horses, (generally mules) and a sod corral sufficient for two or three hundred head of cattle.

There were generally three to five men, a herd of cattle, consisting of oxen for hauling hay and wood and an occasional trip to the Missouri river for supplies. They were always prepared to trade a sound ox for a lame one, and sometimes get its value in "boot" or if a "stray" should be found it was permitted to run with the herd.

Near Kearney we found a man named Charles Dulaney, who was alone. He had a little money and was anxious to go west. Mr. Henry engaged him for his board and lodging to drive the oxen. This released me, so I took a mule and drove loose eattle. Another man, named Jackson, with ox-team loaded with groceries, including some whisky, joined us.

As we approached Cottonwood Springs, about halfway between the mountains and the Missouri, Indians became numerous. They were of the Sioux tribe and had camps down by the river, six or eight miles apart, consisting of from four to twenty lodges. At the spring there were seventy-five. Here were kept soldiers to guard the whites. The other military stations were Kearney, Julesburg and Denver, also Ft. Collins, up the Cache la Poudre. The Indians were inclined to be saucy, and were evidently considering the advisability of killing the whites and taking their stock and goods. Some of them were elaborately painted and in full feather, having their most valued charms attached to their scalp locks, a bounty to the enemy who might be able to take them.

At the first eamp west of the springs we missed an animal of the herd. I went back to our last camp to find it. I failed and was too late to return to eamp, so I tied the mule by a long rope to a telegraph pole and tried to sleep, but was kept awake until late by the noise of a war dance at a large Indian eamp about half a mile away.

The timber on the islands was abundant for about thirty miles in this vicinity. In what were known as the cedar canyons in the hills to the south many thousand ties were cut for the Union Pacific Railroad. A few miles above, timber sud- 
denly ceased and no more was seen for one hundred and eighty miles, so we laid by a day to wash and prepare some kindling wood for our timberless journey. We did not need much wood, as our main fuel was buffalo chips, which in dry weather made an excellent fire but needed a little wood for a starter. In rainy weather they were worthless. The ranchmen gathered wagon-loads and put under cover to be used in wet weather, or if besieged by Indians.

Soon after passing Julesburg, two hundred miles east of Denver, we crossed to the north side of the river to get better pasturage and to escape the clouds of dust raised by the numerous trains that we were continually meeting. In another hundred miles we had scrubby cottonwood timber on the islands. About the same place we came in view of the mountains.

At Fremont's Orchard, eighty miles east of Denver, was a large bottom containing plenty of grass suitable for hay. We went as far as Crow Creek, but not finding things to our liking, returned to Orchard, where elaims were staked, a house built, also a corral, and a large quantity of hay cut. The calves were separated from the cows, of which there were fifty, and cheese-making was begun. This was in August. Jackson and Dulaney staked claims. Mr. Crane, who had left us at Plattsmouth, returned, and Jesse Burkholder, an Iowa neighbor, hired to Mr. Henry to mow. Then we had another man, Jim Weldon. A man and family, refugees from Arkansas, settled just above us. He was a Union man and had to leave Arkansas.

Soon after staking our claims several Confederates from Missouri staked claims below and above us. They hated us, called us Yankees and disputed our lines which had been guessed out without chain or compass. Our cattle horned their hay and they eut over our lines. Finally they stole one of Mr. Jackson's oxen and started some teams back to the Missouri for supplies. We missed the ox at once, overtook the teams bound east and recovered the ox.

This caused much excitement in our camp. One man proposed that we hang every one of them. This was clearly out of reason and not really meant, but we did take an ox team 
down to some hay that they had eut on our claims and captured a load. I don't remember all the details of the battle, only that one man drove the oxen, Weldon and Crane pitched hay and I loaded. Dulaney held the guns, one of which was accidentally discharged, the load taking off part of his hat brim. He put his hand to his head. Weldon dropped his fork and grabbed a gun. Thinks I, "I'll be next,", so I leaped off the load and hurried to the man of guns, only to find how it all was. We seemed to be appeased for we did not take any more hay. I hope to be excused for writing the details, because it was the only battle of the war.

Haying was over late in September. Mr. Henry was out of money, but fortunately a Denver hay-buyer bought of him several loads and it was arranged that Burkholder and I should be paid in Denver. Such loads of hay would be an interesting sight moving along the streets of our Capital; say five loads of four tons to the load, each drawn by five yoke of oxen.

The hayracks were built on wagons of the prairie schooner type, capable of earrying ninety hundred over rough roads. I have seen them with ninety hundred weight of hardware. Long poles from the mountains were used, a suitable reach adjusted and the rack built on the wagon, with a windlass at the rear with poles through it, to insert crowbars to draw down the binding pole. After putting on all that could be conveniently loaded, the wagon was left on level ground to settle, while another was being loaded. Then they were topped out and bound.

I have not mentioned many things that might lead to an understanding of the wild and woolly aspect of the country in its earliest throbs of civilization. Of game, the antelope were numerous but very wild, living in the open country. Deer, not numerous, were found on the islands of the upper Platte, jackrabbits, about three times the size of a common rabbit, everywhere in the open country, grouse and many species of birds: Prairie dogs lived in communities miles in extent, the land suiting them. I saw no living buffalo, but many that had been wantonly shot and left to rot, not even a piece of steak taken. They were in various stages of decay. Some may not 
have been dead more than a month. There were prairie rattlers on low lands but not numerous, often in dog holes in company with small owls. Wolves were common, also an animal smaller than a fox, the name of which I did not learn. I heard them called swifts, coyotes and such.

At Crow Creek I saw an old frontier man named Gerry, who had lived in the country twenty-four years. His wife was an Arapaho princess. He lived in a house, near which were a couple of wigwams, where his mother-in-law and other relations lived. He had quite a family of children, who, as Arapahoes, drew from the government half-rate annuities, while his wife drew full rate. On some low ground near the Platte he had a small field of corn which the squaws were cultivating. It was squaw corn. He told me that eighteen years ago there fell three feet of snow that remained for three months. The Indians lost nearly all of their horses by starvation. Some were saved by felling cottonwood trees so they could get the bark.

During our journey up the Platte we had a few light rains, but the dust raised by the numerous herds and trains was annoying. On one oceasion I observed the sunlight on a dust cloud eaused it to appear white as is often seen on real clouds. A mirage was a common sight, but it always appeared like water, generally a lake in some low place. I saw one place where I could look up-stream until the surface of the river met the horizon. The water flowed at the rate of about eighty miles in twenty-four hours, and the incline of the valley was evident to the eye. A deep current would be too swift to be held by alluvial banks, hence the wide shallow channel. The melting snows in the mountains eaused an all-summer flood which might amount to a rise of ten or more inches or in extreme case, of two feet, but that would be very high. All summer long herds of eattle were passing to the west. A man traveling east stated that he met sixty-nine herds between Denver and Orchard. Opposite our settlement was a ranch and above it a bottom where they eut hay.

Far down the valley and soon after we had crossed to the north side, two men met us about camping time. They said 
they were on their way down to a ranch to work in hay harvest. They had met a friend the morning of that day and drunk freely. Upon resuming their journey they got along nicely until nearly night, when they found that they had left their blankets. They asked for lodging and were accommodated.

There came to us at Orchard a man who told us about these men and the circumstances connected therewith. They said that the men were eattle thieves and had with them fifteen hundred dollars obtained by their craft; that one of the men was Ed. Ingals, who had escaped from the Denver jail, and was fleeing from justice, without bedding, and that they had shadowed them for the purpose of taking in their hides. When a cattle thief has been successful his hide is dry and ready to take by any murderer that gets a good chance. They further stated that they concealed themselves in a ravine not far below our camp and killed these men as they were passing. One of the men who gave this information was called Old Ranger Jones.

During November and December I had occasion to cross the river several times. The eurrent was so swift that it did not readily freeze over, so I sought a suitable place, took off clothing and waded, carrying my clothes. A storm stampeded many herds of cattle. One herd from the Bison, sixty miles away to the northeast struck the Platte where we were, and was seattered along the river for many miles.

A few days later the owners came to look them up. The company was made up of four men with horses, a burro and five dogs. Two men searched for and drove in the cattle. One kept the recovered eattle together, and one stayed with the camp and cooked and the burro carried the bedding, provisions and cooking utensils when they moved to new territory.

Early in January the weather moderated and much of the snow melted. Arrangements were made for passage to the Missouri river by an unloaded train that was returning for freight. I had been homesick for some time, and it gave me great joy to realize that I would soon be on my way home. The fare was ten dollars per man and his baggage. The returning trains earried hundreds of such passengers. They were called 
"pilgrims" for short. We did our cooking in a room, apart from the store room, called the pilgrim house. We could use a sheet-iron cook-stove and sleep on the frozen ground floor, all for ten cents per head, day after day for six hundred miles.

At the end of the first day's travel we stayed at a ranch near an old trading-post ealled Fort Lupton. Here we met an incoming train. So many of us were in each other's way, but good nature prevailed and we were well over our supper when another large mule team rolled in. Then we had the racket all over again, only worse. All hands were disposed to look upon the humorous side of things, moved as I suppose by the very disagreeableness of the mix-up. There was scant room for all to sleep upon the ground.

In one corner of the room an attempt had been made to build a bedstead. The frame, with some poles laid across it, was all there was. A couple of boys made their bed on it. All became, quiet, then one of them arose and sat upon the edge of the bed. "What are you doing?" asked the other. "Resting." That touched off the crowd.

The next morning I examined the ruins of the old fort which had been built many years ago by an old trader named Lupton, as I suppose. It was of sun-dried brick. The woodwork was gone, burned perhaps, but the walls were firm and in places ten feet high. As we were approaching Orchard, perhaps within fifteen miles, we met one of our old foes from Missouri, driving some of Mr. Henry's eattle, which I recognized, and I called the man by name. He was much surprised and confused, but went on. That night I notified Mr. Henry, who took measures to recover the stock.

We stayed at the ranch opposite Orchard. There was a big crowd of pilgrims, much gambling for drinks and several drunk. About fifty miles below Orchard was a ranch owned by the men we were traveling with. Here we stopped a couple of days, turned our horses loose on the prairies on the north side of the Platte, eaught up fresh horses and resumed our journey. We had in our gang a variety of characters. Some of them did not like the rough and ready ways of the country. 
Of course the boys tried to be as rough and uncivilized as they could. They all professed to be lousy and by the time we got to Julesburg it was all a reality so far as body lice were concerned. They were not lice, but gray-backs. They were the occasion of many amusing remarks to our refined friends' genuine dismay.

There was a tract of country here about two hundred miles across, without snow. The pasturage was good and stock in fine condition. We ran into snow at Kearney, where we forded the Platte and in a few miles it was too deep for good wagoning, though almost as suddenly it became thinner. Wood river was less than a day's drive below Kearney. Then eame Northside, a Mormon settlement. There we came to a German settlement where there was a large wind-mill for sawing lumber and grinding grain. I am sure that the wheel was as much as forty feet across.

Half way from Kearney to Omaha we crossed the Loup river, too deep to ford, too much ice to ferry and the ice rotten. Took off the horses and led them with long ropes and pushed the wagons by man power. Arrived in Omaha about noon. Ice on the Missouri too rotten for teams. Hired a man to pilot us across, putting our baggage on a hand sled. All but myself carried poles to eatch on the ice in case of its giving away. I, being the lightest one of the company, thought it safe to keep well in the rear without a pole. I must have walked a little to one side of the track. The ice gave away and I went through, making a round hole about twenty inches across. Throwing out my arms I stopped myself. Crawled out, oh, so earefully, and crawled along the surface until I felt that I might risk standing on my feet. On the east side the channel was open for a short distance. This we crossed in a skiff. The walk to Council Bluffs was four miles, which gave my clothes a chance to drain and kept my blood warm. The next day, late in the evening I reached home, changed my clothes, throwing my old clothes out at the window. It was a mean trick on the gray-backs who had stayed with me so faithfully through the wet and chill, but as I have been telling you the truth all through this story, I'll not deny it now. 
While I was in Colorado my father, G. W. Pugsley, and a neighbor, ran across a buffalo in the south part of Boyer township, Harrison county. The neighbor, being on foot, dropped out of the chase. Father had a good horse. He drove the buffalo in a northeasterly direction, past the house of Joseph Harry, in Douglas township, and that of Matthew Hall. He had just passed the home of Mr. Mefferd when he met the Mefferd boys coming in with a load of hay. They unhitched, mounted their horses and hurried home for guns. After crossing Picayune Creek, he turned the beast to a southeasterly course, passing our own place on Section 22. Here our dog joined in the chase, and about half a mile east, on Section 23, the buffalo eame to a halt after being chased over six miles. The Mefferds soon eame with guns, and after about a dozen shots he fell. The meat was distributed among the neighbors, one family coming fifteen miles just to be able to say they had eaten buffalo meat. This is the only buffalo ever known to have been killed in Harrison county.

\section{A REMINISCENCE OF THE IOWA BAR.}

$$
\text { BY D. C. BEAMAN. }
$$

I think it was in 1874 when Tom Mulvany was indicted for selling whisky at Eldon, in Wapello county.

The prohibitory law was not popular in the railroad and river towns. His trial was in Ottumwa, where the law was then seldom enforced, the juries being disposed to acquit if any excuse was afforded for so doing.

Morris J. Williams was judge, M. H. Jones of Bloomfield was district attorney, and H. H. Trimble and E. L. Burton were Mulvany's attorneys.

An old farmer named Solomon Wilson Hamilton Leger Hearn, who lived near Eldon, was the State's only witness. Sol Hearn, as he was ealled for short, was frequently engaged in litigation, indeed, he said that he had so little confidence 
Copyright of Annals of Iowa is the property of State of Iowa, by \& through the State Historical Society of Iowa and its content may not be copied or emailed to multiple sites or posted to a listserv without the copyright holder's express written permission. However, users may print, download, or email articles for individual use. 